\title{
$\mathrm{X}$ 線検查時の患者被曝線量の軽減について
}

\author{
広島大学原爆放射線能医学研究所 \\ 砂 屋敷忠

\section{REDUCTION OF PATIENT RADIATION DOSE FROM DIAGNOSTIC RADIOGRAPHY}

\section{By TADASHI SUNAYASHIKI}

Department of Radiation Biology, Research Institute for Nuclear Medicine and Biology, Hiroshima University

\section{Summary}

This report dealt with the technical factors to reduce the patient exposure from diagnostic x-ray examination.

According to hospital survey, there were possibilities of dose reduction by the use of high $\mathrm{kVp}$ technique, limitation of field size and the improvement of recording systems including film and intensifying screen. The further dose reduction can be achieved by the introduction of x-ray TV as recording system.

The careful attention should be given to foetal and children examinations which contribute significantly to gonad dose.

It was suggested that the proper. work load for radiolgical technician and daily care of x-ray unit and technique to ensure the best radiographic quality were necessary for minimum patient exposure.

\section{1. 緒言}

国民の医療水準が向上すると共にX線検査の量と検查 内容が着実に増大して来た。乙れによって被曝線量レべ ルが高くなり，人工放射源による被懪占占的医療用放 射線の割合が大きくなるととから，被曝低減が国際的に 提唱 ${ }^{1334}$ され，同時に利益と損失の評価がなされてきた。 わが国においてあ早くからての問題がとりあげられ，

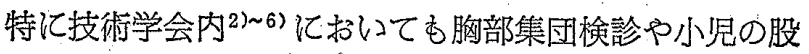
関節撮影時の生殖腺防護, 胎览撮影時の被懪低減なぞに ついて検討されて来た.1973年本会総会シンポジウムで は，X線検查時の患者被嚗の軽減をとりあげ，診断価值 を低下させることなく，被瀑線量を低減するための積極
的な提案がなされた7) 10)。

本報告は，X線撮影時における被曝低減の技術的手法 そついて 2.3 の調查・実施を抢てない，日常実際的な面 で考慮すべき諸点の検討を試みた。

\section{2. 調查および実験方法}

被曝低減の技術的方法のうち最す導入しやすい部分を 知るために，撮影条件の調查をおこない1965年に行われ た胎児撮影汇関する調查 ${ }^{11}$ と比較した。次に照射野につ いて絞り器の精度を，画像処理に関して自動現像機の性 能を各施設について比較し，また再撮影の誘因之頻度を 検討するための調查をおこなった.

調査は広島市および近郊の放射線技師の勤務する病院 
(14)についておてない，再撮影については広島県下の病 院(29)についてアンケート調查を㧍てなった。絞り器晾 よび自現機の調查はそれぞれの施設を訪問して，照射あ るいは現像処理をおてなった。これらは日労の業務と同 一条件で扎となうのを原則とした。また記録系の改善策 を検討するためにX線テレビによる録画像の検討を付加 した。これらの調查および実験の方法の詳細は調查また は実験結果と結びつけて，それぞその項に記述した。

\section{3. 結 果}

\section{3-1 撮影電圧の推移と被曝線量}

X線撮影付もちいられるX線管電圧は，被嚗線量を 減少させる因子として比重が大きい，広島市および近郊 の病院で，被曝線量の低減が問題とされるようになった 頃と現在とで，撮影電圧がどのように変って来たかを調 查した.

胎児撮影（グースマン氏法）の場合を調查したが， との撮影は感受性の高い胎児が全身被曝を受けるし，母 体の生殖腺が線束内にあり，かつ将来む生殖可能年齢で ありうるととから被曝線量に払わ礼る関心屯大きいと思 われる。一方，画質の面加ら極端に厚い部位に吸吸差 の少ない胎児を撮影目的とする点で，画像上の難かしい 問題があり，撮影条件を変えて画質を変えるととは好ま れない撮影といえる。

Tab. 1. 1965, 1973年の撮影条件(胎児撮影 グースマン氏法)と被嚗線量の変化

\begin{tabular}{|c|c|c|c|c|c|c|}
\hline \multirow{2}{*}{ 年次 } & \multicolumn{2}{|c|}{ 撮影電㽵 $(\mathrm{kVp})$} & \multicolumn{2}{|c|}{ 照射量 (mAs) } & \multicolumn{2}{|c|}{ 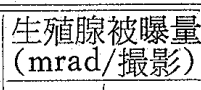 } \\
\hline & 範，囲 & 平均 & 範 囲 & 平均 & 母体 & 胎児 \\
\hline 1965 & $60 \sim 90$ & 74 & $100 \sim 300$ & 180 & 110 & 1,100 \\
\hline 1973 & $70 \sim 105$ & 82 & $10 \sim 200$ & 90 & 46 & 400 \\
\hline
\end{tabular}

1965年の調查は安徳ら11沈っってすでに報告されたが 今回もこれとほぼ同し病院について調查した. Fig.1 に 胎齡35４0週の撮影に採用されている電圧，電流をそれ ぞれ $5 \mathrm{kVp}, 50 \mathrm{mAs}$ 間隔に病院数で示した。電圧では 1973年がより高し電圧に分布し，電流・時間で表わした 照射量 (mAs) は低い値に分布している.Tab.1 亿調查 した電圧, 照射量の平均值と母体执よび胎児の被曝線量 の推定值を示した。線量の推定はガラス線量計で測定さ れたむの11をむちいた。

撮影電圧は両調查の間 8 年に平均で $8 \mathrm{kVp}$ 上昇してお り，照射量は $1 / 2$ になっている。乙れは撮影条件を電 圧・電流・時間で変更する場合の変化に等しいととから，
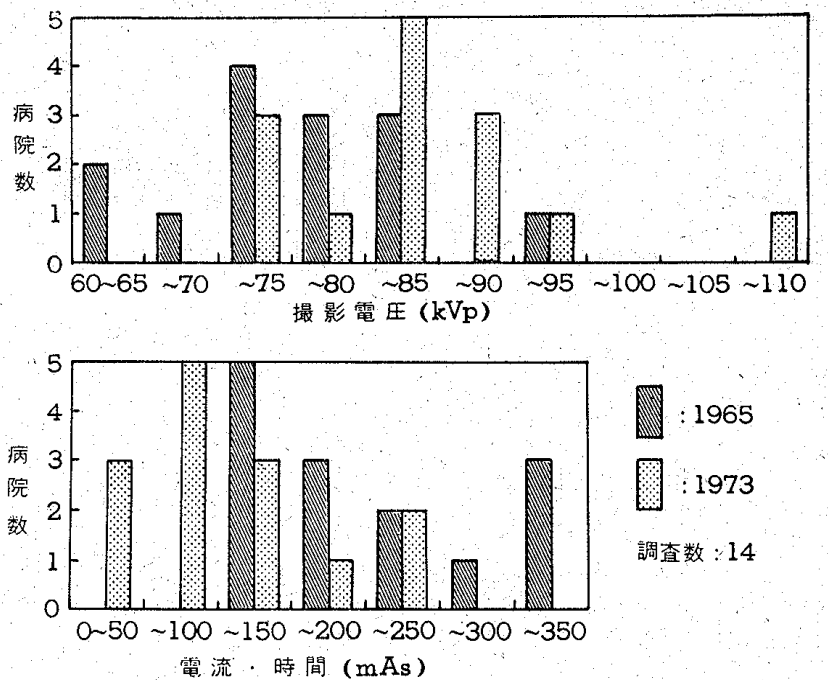

Fig. 1 胎児凛影条件の変化 $(1965,1973$ 年の比較 $)$ グースマン法による

この間に記録系はほとんど変えられていないといえる。 しかし，調查から記録系の高感度型採用が 2 病院でなさ れ，全般的にはこれから高感度型への移行を準備してい る段階であることが示された。

被曝線量は母体・胎児共に生殖腺線量て1965年に比へ てほ正1/2に低下している。

\section{3-2 X 線照射野}

被懪線量の上から照射野の寄与は大きく，乙の点から 多重絞りの精度について多くの調査, 検討がなされてい

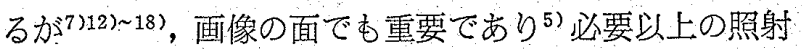
野は問題である。

撮影が絞り器の光指示によってなされているてとが 光指示とX線照射野との関係に注目し, Fig.2 に示すよ うな方法をもちい照射野の精度と共に中心線の精度につ いても測定した. フイルムと同じ大きさ（大四つ切）の アクリライト板 (点線) 、実線で示した $20 \times 30 \mathrm{~cm}$ の大

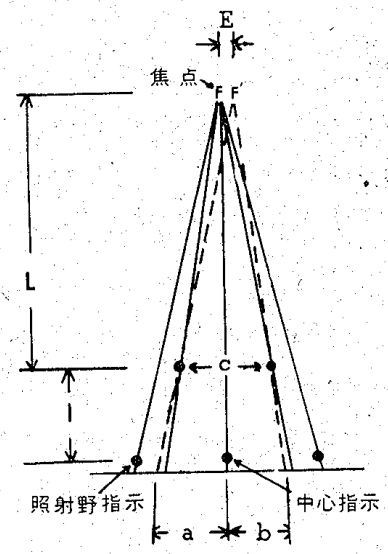

$$
\begin{aligned}
& E=\frac{L}{1} \frac{a-b}{2} \\
& L=1 \frac{c}{a+b-c}
\end{aligned}
$$

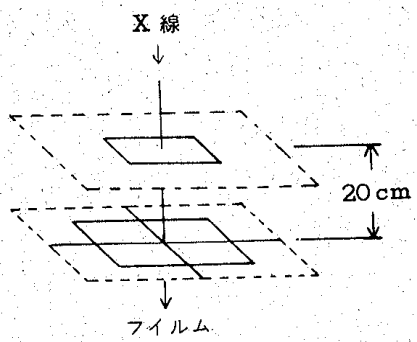

Fig. 2 絞り器の試験法 ${ }^{19}$ 
きさに鈶線を，中央に十字を鉛線で付して，カセッテに

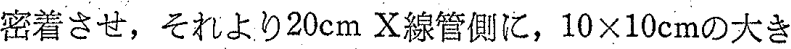
さに鉛線を付した同じ大きさのアクリライト板を固定し た試験用具を作製した。絞り器の光中心を十字に合せ， 同時に上方 $10 \times 10 \mathrm{~cm}$ の中央に一致するようにX線管を 調整し，照射䝑を下面 $20 \times 30 \mathrm{~cm}$ の鉛線に一致させる。 光指示が鉛線に一致しないときは差を測定し記録してお き，フイルムを討測する際補正する，乙の方法はベータ トロン電子線の実效焦点位置の推定にもちいられている あので ${ }^{19)}$ ，撮影でえられたフイルムの計測からFig.2 に 示した式から中心線の位置も求められる.

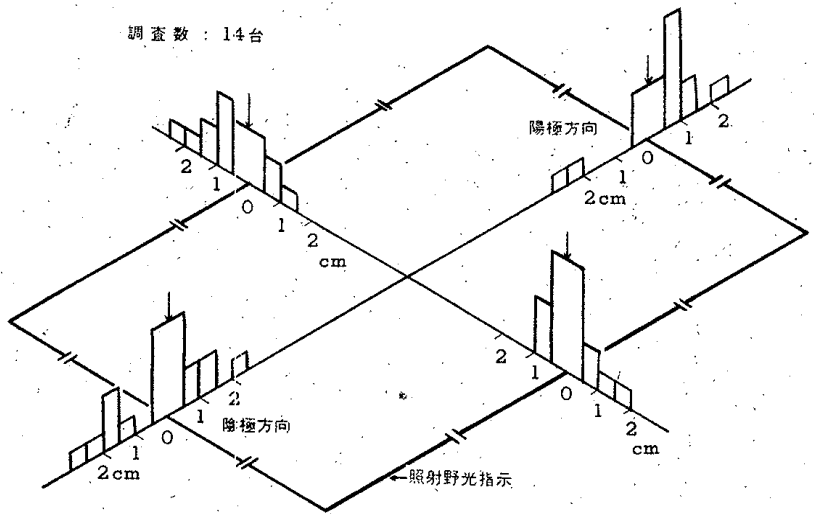

Fig.3 絞り器の光学指示に対するX線照射野のずれ

Tab. 2. 絞り器の光学指示さX線照射野・線束のずれ

\begin{tabular}{|c|c|c|c|c|c|c|}
\hline \multicolumn{4}{|c|}{ 光学指示とX線照射野のずれ } & \multicolumn{3}{|c|}{ 光学中心 } \\
\hline $\begin{array}{l}0.5 \mathrm{~cm} \\
\text { ㅅ. } 下\end{array}$ & $\begin{array}{l}0.5 \sim \\
1 \mathrm{~cm}\end{array}$ & & $\begin{array}{l}2 \mathrm{~cm} \\
\text { 以上 }\end{array}$ & $\begin{array}{l}1 \mathrm{~cm} \\
\text { 以内 }\end{array}$ & $\begin{array}{l}1 \sim 2 \\
\mathrm{~cm}\end{array}$ & $2 \mathrm{cn}$ \\
\hline & & & & $64 \mathrm{C}$ & $21 \%$ & \\
\hline
\end{tabular}

光指示の照射野とX線照射野について14台の多重絞り 器の測定結果をFig.3 に示した. 光学的照射野に対しX 線照射野の違いを度数分布で示したが，Tab.2 のように 約70\%は土1cm以内の違しンであった，X線管の陽極陰極 方向および左右方向での特異性はみられなかった。

光指示の中心がX線束中心と一致しているかどうかの 調查は，X線焦点と光指示の焦点の位置が $2 \mathrm{~cm}$ 以内ず れているあのが85\%であった。ただし，等の撮影条件 ではフイルム面がX線管には平行であるが，絞り器の外 縁に対してある角度をもつ場合が考えられる。

\section{3-3 自動現像機の特性}

自動現像機が普及し，規格化された写真が供給される ようになってきたが，短時間処理への傾向が大きく，90 秒処理吕多〈採用されようとしている.でのようなと から処理時間の違いによって写真特性が異なって来るこ
とも考えられる。ての点について検討する目的で，タン ク現像 2 台およびさくら自動現像機の各種のタイプ12台 について，汎用型フイルムを同一露出して，各々の現像 機で処理して比較した，との場合 Fig.4のような方法で フイルムおよび増感紙の上に水ファントムをおきアクラ イト製の空気階段およびアルる階段による黒化度の比較 を㧍てなった．結果を Fig.5 亿示した．タンク 5 分，自 現機3.5分，1.5分それぞれの平均をまとめて Fig.6 亿示 したが，現像時間別には大きい違いはみられないが， Fig.5のように個々の現像機での差はかなりみられる。
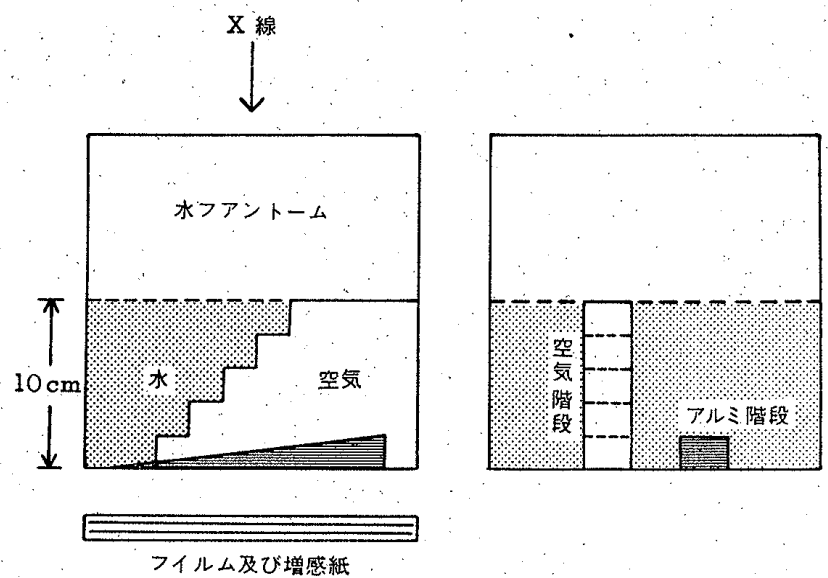

Fig. 4 現像処理の違いによる特性の試験方法

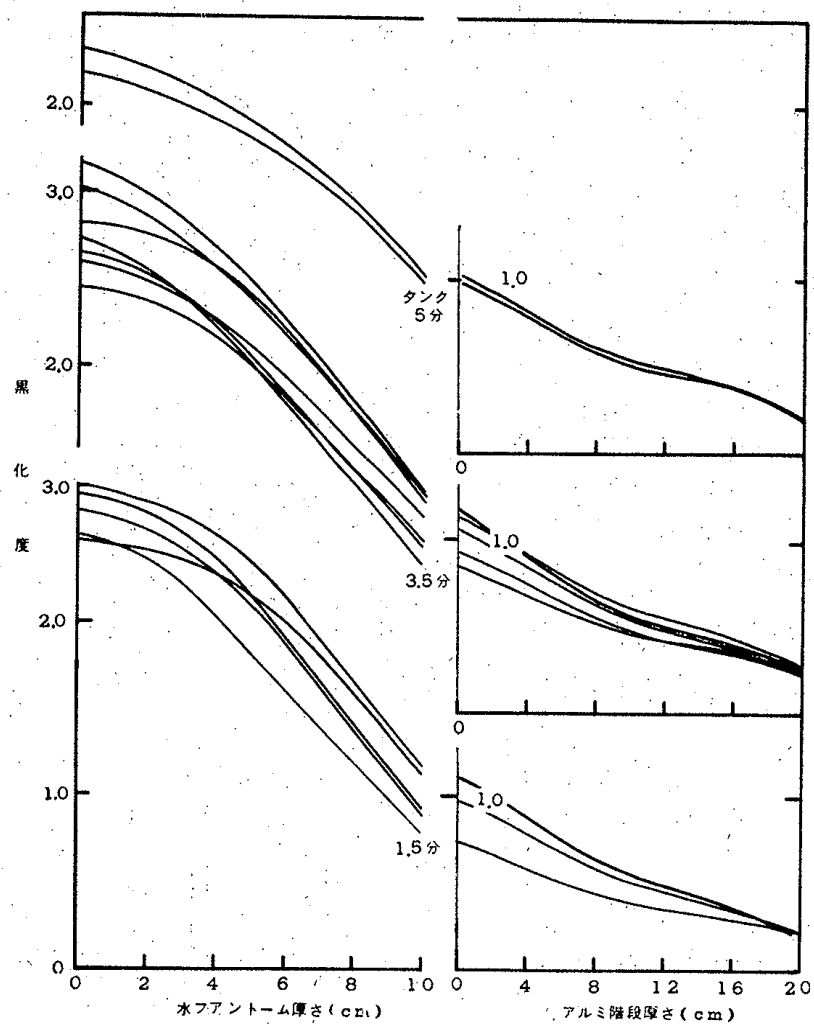

Fig. 5 現像機別の黒化度特性 

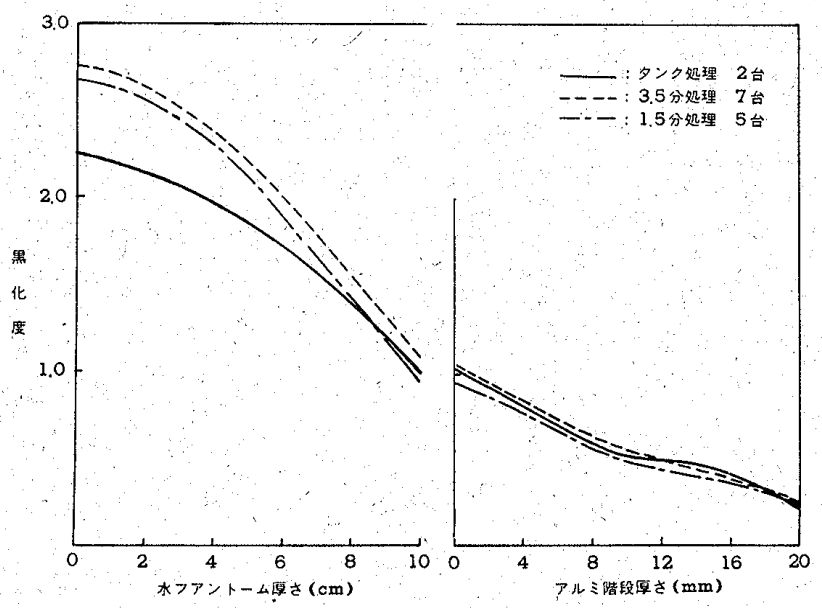

Fig. 6 処理方法別の平均黒化度特性

この差を同一黒化度についてみれば,ファントーム厚さ $2 \mathrm{~cm}$ 程度，照射量认換算して $30 \%$ 程度の違いと考えられ る.

一方，画質の面からの検討を MTF (Modulation Transfer Function) から計算されたレスポンス 関数の 結果をFig.7,8に示した。MTFは黒化度の比較にすちい

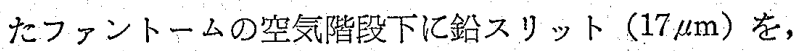
カセッテに密着し撮影したものからあとめた．空気層 2 $\mathrm{cm}$ 下（水 $8 \mathrm{~cm}$ 厚さ）のスリット像で比較したが, 黑化

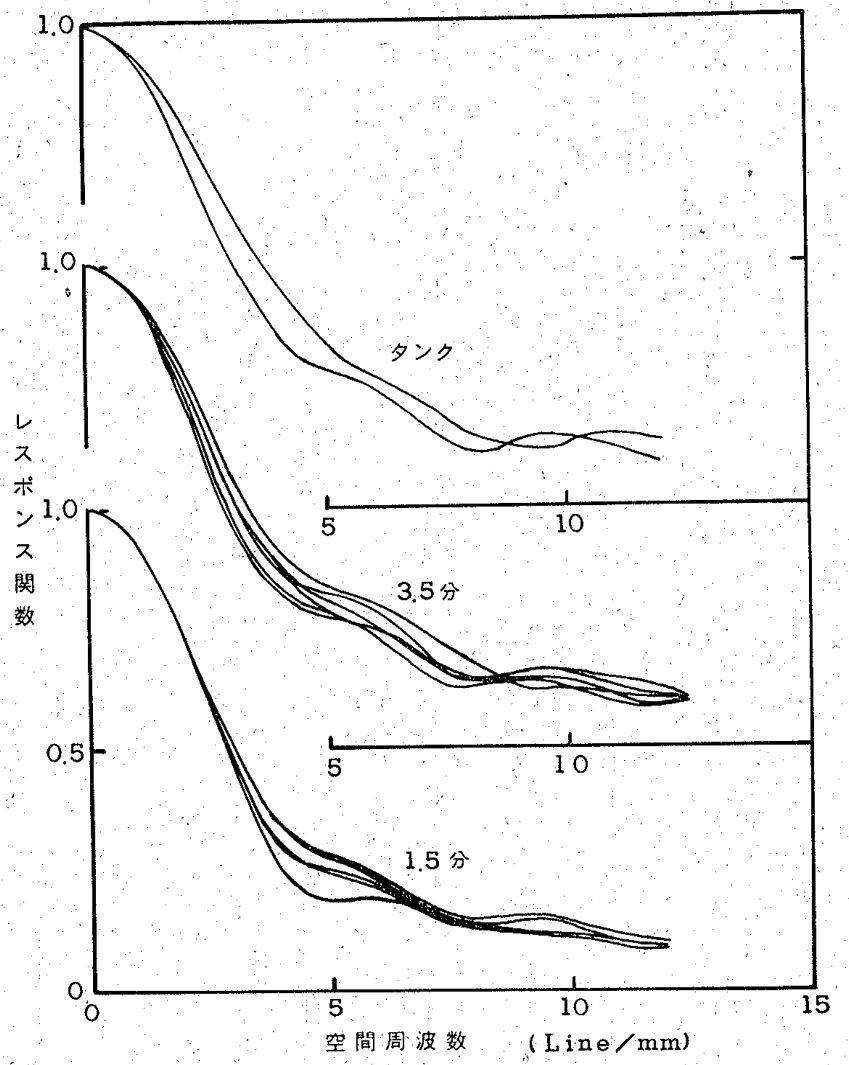

Fig. 7 現像機别の MTF 比較

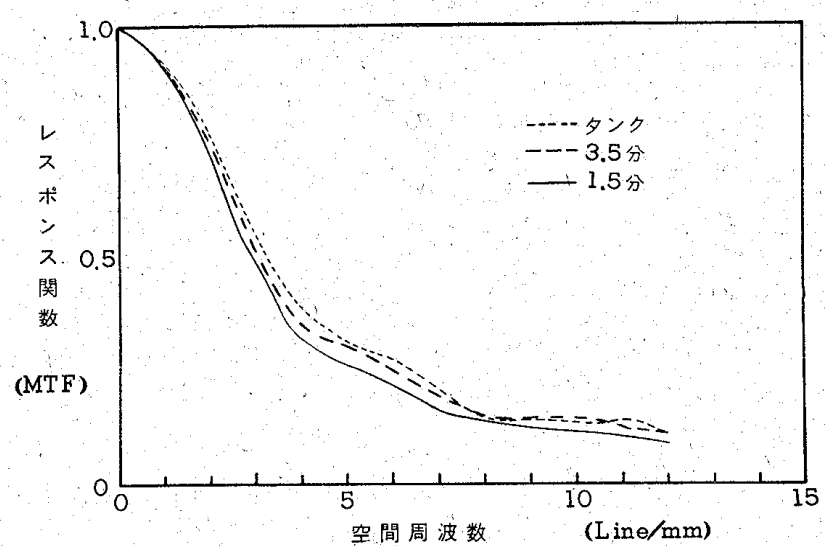

Fig. 8 処理方法別の MTF 比較

度依存性をみるためて空気屬 $4 \mathrm{~cm}$ 下の向ので測定し みてす，乙の実験の範团では大きい違いはなかった：黑 化度の場合と同様に現像時間別の差は大きくなく，個々 の装置での差がみられる。

\section{3-4 再撮影の調查}

再撮影は $2 \sim 3 \%$ 程度であることから 被曝線量への奇 与はあまり大きくないと考えられるが，個々の撮影にと っては 2 倍の被曝となる. 広島県下の複数の診察科を有 する病院を調查の対象とし，一部単科の病院を含め 29 病 院について，昭和48年 7 月から 12 月までの 6 力月間を調 查の期間とした。

作業量と再撮影率につして Fig.9 亿結果をまとめて示 した。再撮影率之診療科数, 技師の平均経験年数, 装置 の台数，補助者数等との相関も求めたが，明らかな関係 はみられなかった。図から技師 1 人当りの 1 日撮影数 30 枚程度まででいくらか再撮影率の低下がみられる一般病 院亡, 撮影数が多く再撮影率の高い多診療科大病院, 撮 影数は多いか再撮影率の少ない胃腸科系儿重点をおいた 專門病院の 3 グループル特徵づけられる。このととを

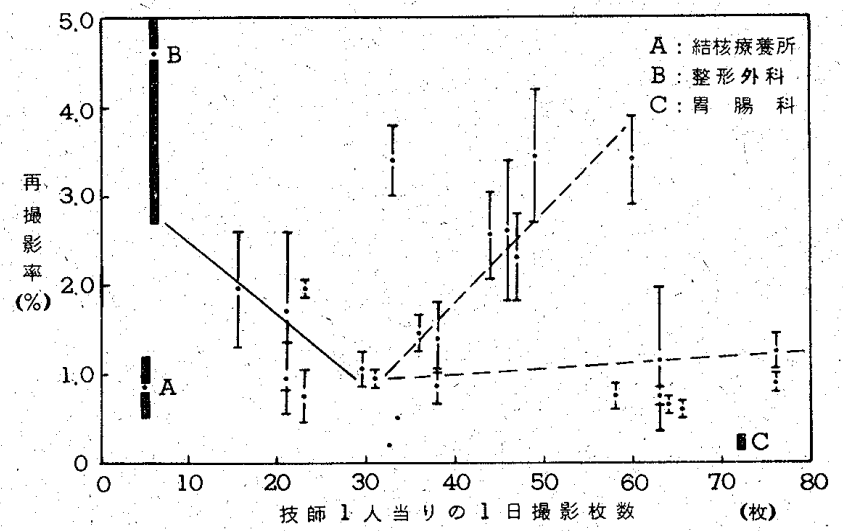

Fig. 9 再撮影率之作業量の関係 (6力月間の平均之標準偏差) 
Tab. 3. 再撮影率, 作業量からみた病院のタイプ

\begin{tabular}{|c|c|c|c|c|c|c|c|c|}
\hline タイプ. & $\begin{array}{l}\text { 痌院 } \\
\text { 数 }\end{array}$ & 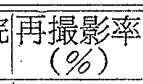 & $\begin{array}{l}\text { 枚数/目 } \\
\text { /技師 }\end{array}$ & 技 & & & & $\begin{array}{l}\text { 放射 } \\
\text { 線医 }\end{array}$ \\
\hline 大型病院 & 6 & $30+$ & $:$ & 5.3 & 13 & & 12 & $0 \%$ \\
\hline 一般病院 & 10 & $1.3 \pm 0.4$ & $28 \pm 8$ & 4.5 & 14 & & $10^{\circ}$ & 0 \\
\hline 胃腸科系病院 & 5 & $0.9 \pm 0.3$ & $65 \pm 6$ & 4.2 & 12 & & 10 & 20 \\
\hline 全調 查料 & 29 & $1.5 \pm 1.1$ & $43 \pm 20$ & 4.0 & 13 & & 9 . & 31 \\
\hline
\end{tabular}

*25年まで 5 年間隔でそれ以上は27.5年とした.

**タイプ分けで明確に区分できないもの8 病院を加え た全調査の平均.

Tab.3 にまとめて示した。

\section{3-5 TV モニタ画像録画}

被曝線量の面から種々の低減方法が採られているが， 特茱な部位で大幅な低減を図るとすれば現状ではTVモ ニタ画像の記録法が優れている。またTV画像はエレク トロニクス回路を介していることから画質的にす従来の 記録法のもたない特長があり，新しい応用の分野が期待 される。
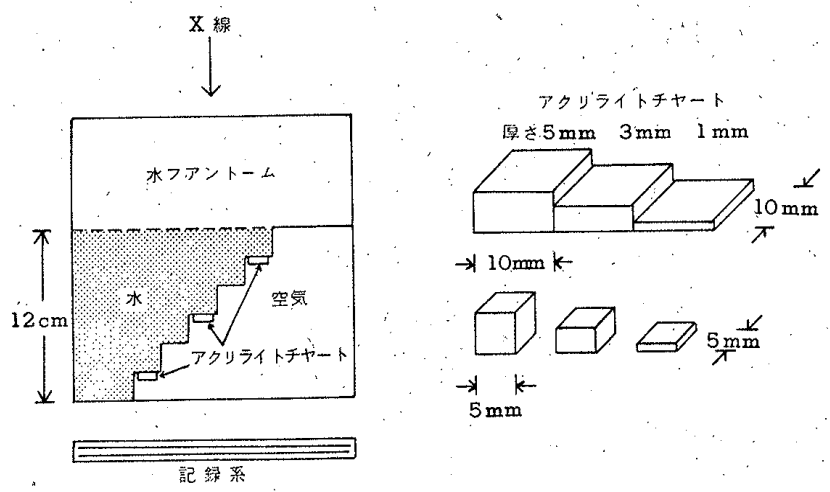

Fig. 10 記録方法の違いによる描出範囲試験方法

観察用の TVモニタ面をポラロイドカメラで接写する 方法でFig. 10 亿示すような水階段中に $10 \mathrm{~mm}$ および $5 \mathrm{~mm}$ サイズのアクリライトチャートをつけて撮影し, 描出の違いをみた。

あちいた装置はライトインテンシファイア(I.I.) と アイソコンをむちいたX線テレビ20)と，イメジインテン シファイア (I.I.) とビシコンをあちいたすの及び直接 撮影で, I.I.+アイソコンをむちいたもの以外は水厚さ $2 \mathrm{~cm}$ 差までのアクリライトチャートを描出したが，I.I. +アイソコンは $4 \mathrm{~cm}$ 差までのアタリライトチャートの 識別が可能であった. Photo.1 にこの装置での肩のX線 像を示した。

被曝線量の測定の結果はTab.4 に示じたが水ファン トーム $12 \mathrm{~cm}$ の表面における線量 $(\mathrm{mrad} / \mathrm{sec})$ で, X線

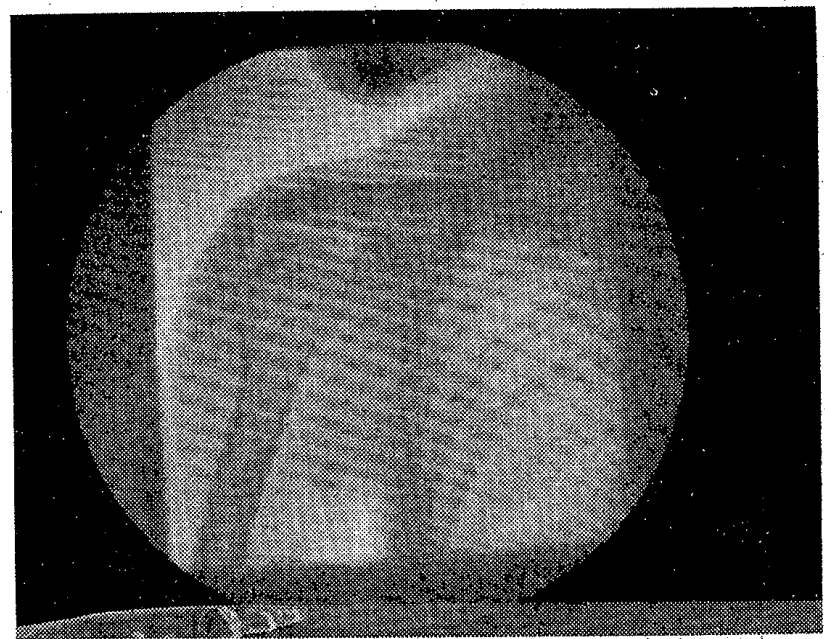

photo. 1 I.I.+アイソコンによる撮影

Tab. 4. I.I.サアイソコンのモニタ撮影時の 被曝線量, 水ファントーム $12 \mathrm{~cm} の$ 表面の線量 (mrad/秒)

\begin{tabular}{l|r|c|c|c}
\hline \hline 電厷 $(\mathrm{kVp})$ & 60 & 80 & 100 \\
\hline 霆 & 0.8 & 5.6 & 13.4 & 25.8 \\
$(\mathrm{~mA})$ & 0.3 & 2.7 & 6.6 & 14.0 \\
\hline
\end{tabular}

一撮影 $1 / 15 \sim 1 / 30$ 秒（ポラロイド撮影) ( $\mu \mathrm{rad}$ )

\begin{tabular}{l|l|l|l}
\hline $0.3 \mathrm{~mA}$ & 90 & 220 & 470 \\
\hline
\end{tabular}

焦点からほぼ $80 \mathrm{~cm}$ 距離でポケット線量計によって測 定されたものである.撮影はモニタ画像の走査線の関係

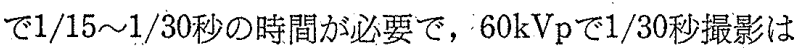
$90 \mu \mathrm{rad}$ 程度であった。

\section{4. 考察}

\section{4-1 低減の目標}

被曝線量低減について目標を示して，乙れに対する技 術的手法を考えることは，実地的な具体策を求めるため 亿有意義である。医療被曝が職策上の被曝に係わる最大 許容被嚗線量の域外にあることから，それが国民線量に 寄与する割合またはその線量限度を厳密に規定すること は簡単ではないが，K.Z.Morganによると，診断用被曝 における遺伝有意線量を当面 40 mrem.とし，努力目標之

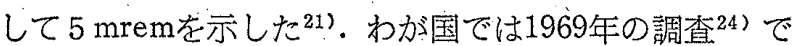
X線検查による国民遗伝有意線量を26.5mremと，報告さ れている.1974年橋街は日本における目標を $10 \mathrm{mrem}$ と 現状の $1 / 3$ にするよう提陧した ${ }^{22)}$.とれらは透視および 診断を含む診断用被曝が対象とされている。

本報告では，診断用撮影についてのみ考察するが，撮 影数の今後の增加とも合せて考えるとことする。撮影数 
はICRP によると23)，医療の先進国では年間の増加祭を 5〜15\%と見積っているが，日本に打ける1960年と 1971 年の調查24ではほぼ20\%の増加率がみられる。広島市に おける撮影の調查加竹下ら ${ }^{25}$ 亿よって報告され，乙れか らみると1966年頃からの増加率は一定し，23\%程度と完 られる.とれらのことから今後のわが国における年間増 加率は15〜25\%程度と見積って大きなあやまりはないと 考えられる.とれは $3 \sim 5$ 年で撮影数汃2 倍となるてとを 示しており，現状の被曝線量を増加させないためには 3 年間のうちに個々の撮影で生殖腺線量を $1 / 2$ 亿するか遺 伝有意線量に対する寄与の大きい撮影 ${ }^{2434}$ 亿対する被曝 線量の大幅な低減を考える必要がある。

\section{4-2 低減のための技術的手法}

診断目的にあった画質を維持しながら被曝線量の低減 をはかるために，どのような技術的な手法を採用するか は重要な問題である。

撮影条件調査から，まず撮影電灰がより高い值を採用 されており，続いて記録系の変更加考慮されているとと がうかがわれた。撮影電圧を上昇するととによって被曝 線量の低下は，問題とする場所が線束内であるか石かに よってかなり異って来るが，一般的に容易な方法である といえる.

線束内にあるときは本報告の撮影条件調查や ICRP の 刊行物その他多くの報告汃らあ明らかなように非常に有 效な手法で，Tab.5 に示したように60kVpから80kVpに 変更すれば 6〜7 割の線量で撮影できると期待されるが， 線束外にあるときは Epp ら ${ }^{26)}$ 安德 ${ }^{28)}$ の データからの 計算で，生殖腺線量の低下はあまり望奴い。毛論， 線束外の生殖腺被曝線量線束内にあるときに比較して 低しととは当然である。骨髄線量につけては電王の上昇 にとすない低下するととは，生殖腺が線束内にあるとき

Tab. 5. $60 \mathrm{kVp}$ から $80 \mathrm{kVp}$ 亿撮影電圧を変化し たときの被曝線量の変化. $60 \mathrm{kVp}$ を 1.0 として, 胸部正面撮影の Epp et al及び Antoku et alのデータから計算

\begin{tabular}{|c|c|c|c|}
\hline \multirow{2}{*}{ 照射野と生殖腺の位置関係 } & \multirow{2}{*}{ 骨髄線量 } & \multicolumn{2}{|c|}{ 生 殖 腺 } \\
\hline & & 男 & 女 \\
\hline 生殖腺が線束外にあるとき & ほぼ 0.50 & $0.8 \sim 1.1$ & $1.0 \sim 1.3$ \\
\hline $\begin{array}{l}\text { 卵㮐が線束の半影にあると } \\
\text { 巳 }\end{array}$ & ほぼ0.55 & $0.6 \sim 0.8$ & $0.7 \sim$ \\
\hline 卵巣が線東内にあるとき & - & $0.6 \sim 0.8$ & $0.6 \sim 0$ \\
\hline
\end{tabular}

ICRP Publication 16 加ら

\begin{tabular}{l|l|l|l|}
\hline 生殖腺が線束内にあるとき & 0.6 & 0.9 \\
\hline
\end{tabular}

と同様であるが線東内の各部に問題とする場所（赤色骨 髄）が存在するととから低下率は小さい。

画質の面からは，特にMTFによる評価で一般に高い 電庄の方が情報量が多いといわれているが，現状の情報 処理の方法加ら考えて撮影電圧は，撮影部位に応じて適 当な範囲があるものと思われ，乙の範囲内でより高い電 圧を選択するととが必要である。

照射野は固定照射筒むかなり使用されているが，可変 絞りに変りつつあることは被懪低減の上加らも，画質の 面汃らあ望ましい：今回の調査汃らは絞り器の精度が大 きな問題となる程，悪いものはみられなかった. Essenburg がカナダで133個の絞り器てついて調查した結果, $12 \%$ NCRP が勧告した適合条件に調整不能であった

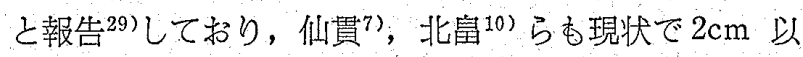
上光指示と異っているむのを $10 \sim 20 \%$ と報告している. われわれの調查も台数を多くしてゆけば，欠楩のあるも の，調整不能なむのに出合ったと思われるが，個々の使 用者の調整や製品の改善がいくらか認められる結果であ った。

線量の点からは照射野辺縁から生殖腺までの距離 $2 \mathrm{~cm}$ の違いで散乱線量はほぽ 2 倍近く見込まれること 生殖腺がごく近い場合は半影内に入るか，線束内に入る かで線量に大きな違いが生ずる結果となり照射野の設定 そ細心の注意を要する。特に精度が不十分であることか らも，使用にあたって広めの照射野がこられる傾向にあ

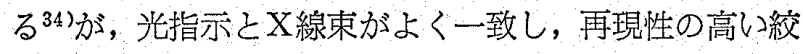
り器で半影および焦点外X線の除去の能率のよいものが 必要である。との報告で用いた絞り器検蒩法は比較的操 作が簡単ですあり，各施設で積極的に採り入れて貪いた いあのである.

現像処理の過程でフイルムの情報量がそとなわれると とがあってはならないが，調查の結果では現像時間別よ りあ同一タイプでも個々の装置のあいだで違いが大きか ったととからも，フイルムと指定された処理剤との組合 せや日常的な点検管理をなおざりにしないととで，特に 問題となるととはないと考えられる. 情報量の点から， MTF の比較をおとなったが，MTF 法では自動現像機 を用いた像の測定にあたって，写真效果が忠実に反映さ れないという問題（「像のやせ小の小等）があり，従っ

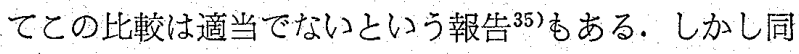
一メーカのフイルムと自動現像機の組合せでは, 黒化度 特性の比較と同様に現像時間を異にするタイプの違いよ りも自動現像機の管理の仕方によって差が生ずるような 結果がえられた。 ここでフイルムおよび自動現像機を一 社製に固定したのは，黒化度およびMTF による画像の 
相互比較を単純な系でおてなうためのあのであった。と の調查加ら設置された自動現像機の性能が十分発揮でき るためには, 補助設備（温度・水量・電力・スペース） の充実と同時に管理の重要性があげられる。

\section{4-3 被曝低減のための重要対象}

X線撮影の種々な対象でまず若年者の撮影について重 点的な被曝低減をとりあげる必要がある ${ }^{36337}$. 若年者の 定義を広くして, 胎児期, 新生児から就学までの奻児期 それ以後成人に達するまでの時期に分けてみても，それ ぞれに問題となる撮影部位も, 撮影条件も大きく異る。 胎览期においては放射線生物学上多くの問題を含み, 胎 龄その他検查を行う諸要素について子予め十分検討するて とが重要である38.

撮影条件調查, 絞り器調查からあ推察できるように画 質的にも，撮影体位や固定が若年者の場合成人に比して 困難な因子が多く, 被曝線㫪低減への条件変更が遅れや すい. 照射野に関しても成人よりも更に大きく選ばれや すい.とのように個々の撮影で被曝線量レベルが高くな ると同時に, 今後の医療被曝の機会はさらに多くなるこ とが考えられる. 子供期待数も大きく国尼遺伝有意線量 への寄与が大きいので, 被曝線量低減への種々の技術的 手法をとのグループに適用することが必要である.

\section{4-4 診断目的別の撮影条件の選択}

被曝線量之画質の関係は今後の撮影の諸条件の変更を 必要とするが，現状では特に生殖腺を含む撮影対象につ， いて撮影電圧の範国を再检討する必要がある。次にフイ ルム・増感紙の選択を撮影対象別にできるようにするて と，一部の撮影対象については，現像処理を広範囲型に するような画質の変更によって情報量の増加をはかれば 撮影回数の低下で被曝線量の低減屯考えられる39740)。乙 のような考えから大幅に被曝線量の低減を必要とする対 象，例えば胎児・乳幼児の撮影および連続撮影飞関して TV モニタの録画方式は非常に有効で, 被曝線量低減亡 同時に従来の考えにとらわれない診断目的に沿う種々の 画質が考慮されてよいであろう.X線 TV の記録系の改 善はこれらのととから有意義である.

\section{4-5 作業量の適正化}

再撮影調査汃ら再撮影の被曝線量への寄与 ${ }^{41}$ は, 全体 的にみてそれほど高いあのとは考えられない：しかし一 般撮影の作業量が 1 日30枚をてえると再撮影の增加の傾 向がみられることから, 防護に対する配慮屯低下するこ とが推察され 23 ，被暴低減への完全な技術的手法をあち いるととが困難になって来るすのと考えられる. 人員の 適正な配置と作業空間の機能的設計むしくは改造等が最 あ望まれる。

\section{4-6 撮影技術の再点検}

現状の技術を再検討して被曝線量低減への方法を企て るととは重要なステップである・すなわちただ一つの手 法で目的が達せられるものでないととから，総合的な対 策が必要である.Tab. 6 江生殖腺被曝線量の大きさ別の 撮影対象で検討ずへき項目を示した：ことで画質の向上 で余分な撮影を少なくしてゆくことが被懪線量の低下に つながる40)というととは大切で，との点も合せで考える 必要がある。

生殖線量の低減を考えれば，一般には他の問題となる 臓器についての被曝線量も低下するととが考えられるが 例えば胸部撮影のような場合42)は骨髄線量についての配 慮が必要であり，全撮影対象を通じて容積線量の低下 ${ }^{43}$ に着目することも肝要である。

Tab. 6. 被曝線量と画質を考慮した点検事項

\begin{tabular}{|c|c|c|c|}
\hline \multirow{2}{*}{ 項 目 } & 生 & 殖 腺 線 & 量 \\
\hline & 高被曝群． & 中被曝群 & 低被曝群 \\
\hline 撮影電圧 & $\begin{array}{l}10 \mathrm{kVp} \text { 程度 } \\
\text { の上舁 }\end{array}$ & & \\
\hline フイルタ. & \multicolumn{2}{|c|}{$\begin{array}{l}\text { 2〜4mmAl は必要 } \\
\text { 特に単相の装置 }\end{array}$} & \\
\hline 撮影距離 & \multicolumn{2}{|c|}{$1 \mathrm{~m}$ 以内は䦞題がある } & \\
\hline 電流・時間 & \multicolumn{3}{|c|}{ 短時間・大電流撮影 } \\
\hline 陽極効果 & \multicolumn{3}{|c|}{ X線管陽極側が線量が少ない } \\
\hline 照射野 & 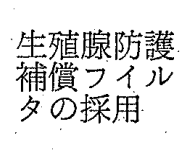 & $\begin{array}{l}\text { 照射野のわず } \\
\text { 加な違いで生 } \\
\text { 殖腺が線錐内 } \\
\text { に入る }\end{array}$ & $\begin{array}{l}\text { 撮影体位で } \\
\text { 線錐之生殖 } \\
\text { 腺が近ず } \\
\text { とどある }\end{array}$ \\
\hline グリッド & 適正な利用 & \multicolumn{2}{|c|}{$\begin{array}{l}\text { 不必要な使用や高格子比の } \\
\text { 使用は䦓䟎 }\end{array}$} \\
\hline $\begin{array}{l}\text { フイルム } \\
\text { 増感紙 }\end{array}$ & 高感度型へ & 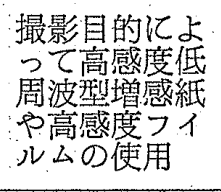 & \\
\hline 写真処理 & \multicolumn{3}{|c|}{ フイルムの情報を最大限とりだす方法 } \\
\hline 機材管理 & \multicolumn{3}{|c|}{ 装置・絞り器等の日常管理システム確立 } \\
\hline 技術管理 & \multicolumn{3}{|c|}{ 科学的撮影と記録 } \\
\hline \multirow{2}{*}{ その他 } & & \multicolumn{2}{|c|}{$\begin{array}{l}\text { 胸部撮影では骨髄線量が問 } \\
\text { 題. 撮影対象が多い.・防護 } \\
\text { が必爱. }\end{array}$} \\
\hline & 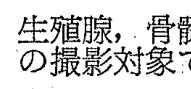 & $\begin{array}{l}\text { のみならず他 } \\
\text { 被曝軽減と画 }\end{array}$ & $\begin{array}{l}\text { 器官の全て } \\
\text { 铜上か必要. }\end{array}$ \\
\hline
\end{tabular}




\section{5 結 論}

X線撮影時の被曝線量低減について，技術段階での手 法について検討した：10年来の技術的な検討がなされて いる結果を総合的に有効に利用すれば，低減目標安達成 できる方法はのこされており, 更に大幅な低減の方法も 開発可能である.このととから被懪線量低減への今後の 成果は十分期待できるといえる.

謝辞、稿を終るに当り報告の機会を与えていただいな 阿部二夫学会長，で指導賜りました座長の石坂正綱氏に 感謝いたします。終始で指導とで援助賜りました当研究 所竹下健児教授, 安德重敏助教授始好教空の皆㥞に心か ら感謝申し上げます，また広島大学医学部附属病院の土 井信一格技師長始め技師の皆樣には実験・討諭を通じて 多くの協力をいただきむした．MTFの計算について大 阪大学速水昭宗氏ので教授をいただきました：記して深 謝申し上げます。

\section{文献}

1) ICRP Publ.16 X線䪭断に㧍ける患者の防護. 日本 アイソトープ協会, 1972 .

2）近藤民雄：患者の被懪線量の軽減. 日放技学会誌, 14, 67, 1958,

3) 広住治夫：診察時における被裀線量, 被検者の被曝. 日放技学会誌，16，150-169，1961.

4）熊谷定義：被検者被曝線量の減少之関係諸因子につ いて，日放技学会誌 $17 ， 64-74 ， 1961$.

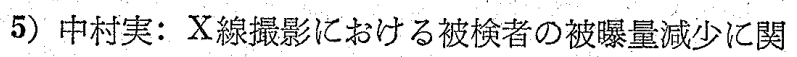
可基礎的研究，日放技学会誌，17，79-83，138$142,209-216,18,1-6,1961-1962$.

6）佐藤大令：X線撮影時にフイルム亿及ぼす散乱線の 影響について, 日放技学会誌, 17，186-207，1962.

7) 仙貫忠夫：X線検查時の患者被曝線量の軽減につい て I, 日放技学会誌, $29,220-227,1973$.

8）後藤勝正：X線検查時の患者被曝線量の軽減につい てII，日放技学会誌，29，228-236，1973.

9) 宮下五郎：X線検査時の患者被曝線量の軽減につい てIII, 日放技学会誌，29，237-249, 1973.

10）北富隆：医療被瀑軽減の問題点: 日放技学会誌. 29 250-255, 1973.

11）安徳重敏, 砂屋敷忠, 吉永春馬, 田淵昭, 中川繁: 螢光ガラス板線量計による胎览撮影時の被嚗線量の 測定， 日医放誌，25，50-57，1966.

12）中村 実；X線写真の画質に捄よばす因子の研究， 日放技学会誌, $20,243-290,1965$.
13）小村良昭: 多重絞りの漏洩線量の測定, 日放技学会 誌, 24, 118, 1968.

14）木村正一，真壁宗一：多重絞りの性能について，日 放技学会誌，28,106, 1972.

15）木村正一，金友高史：多重絞りの性能について，日 放技学会誌，28，107，1972. 。

16）山本喜代志：多重絞り羽根の位置ともれX線の関係, 日放技学会誌, $28,107,1972$.

17）段床嘉晴, 山下一也, 森嘉信, 花山正行, 小水 満，中村幸夫, 坂下善治, 川越康充，木元治幸：欠 楩のある多重絞り器について, 日放技学会誌, 29 , $140,1973$.

18）沢田武司，堀部紀夫，長縄治郎：多軌道断層装置の 応用について，日放技学会誌，29，343-355，1973.

19) ICRP Report 21: Radiation Dosimetry, Electrons with Initial Energies Between 1 to $50 \mathrm{MeV} .1972$

20）上総中童： NEC 最近のX線テレビシステムについ て, 映像情報, 5, 70-72, 1973.

21) Morgan, K. Z.: Why the 1968 act for radiation control for health and safty is required. Radiology, 99, 570-579, 1971.

22）橋詰 雅：第12回原子力総合シンポジウム, 毎日新 聞, 2 月18日, 1974 .

23) ICRP Statement: Patient exposures in diagnostic radiolgy: Protection problems of current conaern. Health Physics, 25, 619-621, 1973. 邦䚿，日放技学会誌，29，507-510，1973.

24) Hashizume, T., Kato, Y., Maruyama, T., Kumamoto, Y., Shiragai, A. and Nishimura, A.: Genetically shignificant dose from diagnostic medical $x$-ray examinations in Japan, 1969. Health Physics, 23, 827-843, 1972.

25）竹下健児：医療用放射線被曝の実態，第10回放射線 影響懇話会（九州） 9 月, 1973, 放射線生物研究, $8,50,1973$.

26) Epp, E. E., Weiss, H. and Laughlin, J. S.: Measurement of bone marrow and gonadal dose from the chest $\mathrm{x}$-ray examination as a function of field size, field alignment, tube kilovoltage and added filtration, Br. J. Radiol 34, 85-, 1961

27) Antoku, S. and Russell, W. J.: Dose to the active bone marrow, gonads, and skin from roentgenography. Radiology, 101, 669-678, 1971.

28) Antoku, S., Russell, W. J., Milton, R. C., Yoshinaga, H., Takeshita, K. and Sawada S.: 
Dose to patients from roentgenography. Health Physics, 23, 291-299, 1972.

29) Essenburg, A. and Koziarski, B.: Alignment of light-localized beam and radiographic $x$-ray beam. Radiology, 104, 716, 1972.

30) Morgan, R. H., : Gonad exposure in medical radiography. $A$ hand book of scatter/primary exposure ratio. Public Health Service Publication No.2001

邦訳引用, 日放技師誌，21，特集，79-82，1974.

31）提 直葉，宇佐美達也：腸X線検査に打仃る患者の 生殖腺被曝線量，日放技学会誌，29，46-51，1973.

32）花山正行, 森 嘉信, 雄川恭行; 伊藤慎弥他: 熱螢 光線量計の使用経験，日放技学会誌，29，101， 1973.

33）秀章之助, 藤原 治, 後藤勝正, 宮原 徹, 中野是 弘他：X線撮影時における直接線錐外の体内散乱線 について，日放技学会誌，29，102，1973。

34) UNSCER: lonizing radiation: Levels and effects. Vol. I, 1972.

邦訳 国連科学委員会，1972年報告，放射線のレベ ル，原子力安全研究協会 1974 .
35）稲津 博, 永田耕作, 猪々倉政盛, 森本雅博: フイ ルム等方性の自現機认よる乱れ，日放技学会誌，28， 202-206, 1972.

36）柄川順：小児の放射線許容量，小皃臨末， 26 , $646-649,1973$.

37）北皇 隆：低線量被曝による障害の評価, 臨床放射 線, 17, 115-121，1972.

38）田淵，昭：放射線による胎児障害，第16回日産婦学 会宿題報告, 1974 .

39）館野之男：X線写真その診㕬目的と画質と被曝線量， 放射線科学，17，41-48，1974.

40）西岡清春：患者被曝防護之腹部 - 消化器X線診断, さくらXレイ写真研究, 25, 5-8, 1974.

41）古賀佑彦：X線撮影時に患者のうける余分の被曝, 日医放誌，27，1387-1391，1968.

42) Kitabatake, T., Yokoyama, M., Sakka, M. and Koga, S: : Estimation of benefit and radiation risk from mass chest radiography. Radiology 109: 37-40, 1973.

43）山本洋一：X線撮影時の患者の被曝線量について, 第 4 回国際放射線技術学会議記録, 277，1969. 